\title{
A Case of McCune-Albright Syndrome Associated with Gs alpha Mutation in the Bone Tissue
}

\author{
Haluk SARGin, Hulya GOZU, Rifat BIRCAN*, Mehmet SARGin, Melike AVSAR*, \\ GAZENFER EKINCI**, ALI YAYLA***, ILKER GULEC ${ }^{\#}$, MUSTAFA BOZBUGA ${ }^{\#}$, BEYAZIT CIRAKOGLU* \\ AND REFIK TANAKOL \#\# \\ Section of Endocrinology and Metabolism, Department of 1st Internal Medicine, Dr. Lutfi Kirdar Kartal Education Hospital, Istanbul \\ 34865, Turkey \\ *Department of Medical Biology, Marmara University Medical Shool, Istanbul 34668, Turkey \\ **Department of Radiology, Marmara University Medical School, Istanbul 81190, Turkey \\ ***Department of 1st Internal Medicine, Dr. Lutfi Kirdar Kartal Education Hospital, Istanbul 34865, Turkey \\ \#Department of 2nd Neurosurgery, Dr. Lutfi Kirdar Kartal Education Hospital, Istanbul 34865, Turkey \\ \#Department of Endocrinology and Metabolism, Istanbul University Medical School, Istanbul 34390, Turkey
}

\begin{abstract}
The syndrome of McCune-Albright syndrome (MAS) is clasically defined as a triad presentation with the findings of polyostotic fibrous dysplasia, café-au-lait spots, and sexual precocity. However, not all patients present with complete symptoms. A 52-year-old man was diagnosed as having a variant of McCune-Albright syndrome with the following findings: polyostotic fibrous dysplasia, acromegaly due to pituitary tumor and subclinical hyperthyroidism due to toxic multinodular goiter. Sexual precocity and café-au-lait spots were not noted. Acromegaly was confirmed by laboratory examination (IGF-1, glucose suppression test and TRH stimulation test). Long acting somatostatin analogue was used as treatment. Although the pituitary tumor could not be removed due to technical problems, mass lesions on the cranium were removed subtotally. Histopathological evaluation demonstrated that the lesion complied with fibrous dysplasia. Genomic DNAs were isolated from the craniofacial bones and peripheral leucocytes of the patient. After amplifying the related regions, Gs alpha (Gs $\alpha)$ gene was analysed by automatic DNA sequence analysis. An activating mutation of the Gs $\alpha$ gene (Arg 201 Cys) was found in the genomic DNA isolated from the bone tissue of the patient, but not in the genomic DNA isolated from the blood. We described a case of MAS associated with Gs $\alpha$ mutation in the bone tissue, presenting with polyostotic fibrous dysplasia, subclinical hyperthyroidism and acromegaly.
\end{abstract}

Key words: McCune-Albright Syndrome, Acromegaly, Gs alpha mutation

(Endocrine Journal 53: 35-44, 2006)

MCCUNE-ALBRIGHT syndrome (MAS) is a classic triad presenting with the findings of polyostotic fibrous dysplasia (FD), café-au-lait spots and sexual precocity. However, a wide variety of endocrinopathy including hyperthyroidism, hypercortisolism, hyperparathyroidism, hyperprolactinemia, hypersomatotropism, hypophosphatamic rickets and hypothalamic hypogonadotropic hypogonadism have also been described with this

Received: February 15, 2005

Accepted: September 26, 2005

Correspondence to: Hulya GOZU, M.D., Kozyatagi Mah. Beyaz Kanarya Sok. Inmak Sitesi. Sena Apt. B Blok. Daire: 5 Erenkoy/ Istanbul/Turkey 34742 syndrome [1-3]. It was first reported by McCune in 1936 and shortly after by Albright et al. in $1937[4,5]$. MAS is rarely associated with hypersomatotropinemia. To date, 59 cases of MAS with acromegaly have been reported $[2,3]$.

cAMP has the ability to stimulate both proliferation and differentiated function of certain cell types, especially endocrine cells and melanocytes. An activating Gs $\alpha$ mutation could explain many features of MAS [6]. The analyses of Gs $\alpha$ mutation were only genomic and the majority of them are point mutations at the Arg 201 position, characterized by Arg 201His or Cys [6]. Gs $\alpha$ mutations were identified in few patients with MAS to date $[3,7-25]$. 
Here we described another variant case of MAS associated with Gs $\alpha$ mutations in the bone tissue, who presented with polyostotic FD, subclinical hyperthyroidism and acromegaly.

\section{Case Report}

This study was approved by the Ethical Committee of Dr. Lutfi Kirdar Kartal Education Hospital and signed informed consent was obtained from this patient. A 52-year-old man was referred to an orthopedic clinic with the complaint of continous pain in his right thigh. Increase in size and distortion of the right face had been noted since the age of 12 . The enlargement of the hands and feet had also begun during the same years. He had a history of fracture in the pelvis twice at the age of 15 . Development of his secondary sex features was normal. He had loss of vision in the right eye at the age of 30 (Fig. 1A). He had a waddling gait since the age of 30 and after this time he could only walk with a crutch.

He weighed $98 \mathrm{~kg}$ and had a height of $162 \mathrm{~cm}$. He had an asymmetric face with coarse features and acral enlargement (Fig. 1B). There was a painless, hard tumoral mass which involved right maxilla, zygoma, temporal bones, and protruded to the nasal cavity with irregular borders. The right eye was protruded. The posteroanterior diameter of the chest was increased. The patient had kyphosis. His right lower extremity was atrophic. Bowing deformity was present on both limbs. Ankylosis was present on both hips with flexion at $40^{\circ}$ for right and flexion at $70^{\circ}$ for left sides. Enlargement of the hands and feet was also noticed. Nasal septum was deviated to the left. Patient's visual acuity was $20 / 20$ vision on the left and finger count from $20 \mathrm{~cm}$ on the right. The fundus was markedly pale which was compatible with optic atrophy on the right and was normal on the left. The visual field could not be evaluated because of the size of his head.

Laboratory studies related to endocrine profile of the patient are shown in Table 1.

Radiographic examination showed extensive involvement of the skull, mandible, pelvis, vertebrae and lower extremities. A ground-glass density was apparent with a relative increase in the diameter of medullary space in the extremities (Fig. 2A). X-rays of the skull showed gross enlargement of the skull, facial bones and mandible with irregular thickening of the base and the loss

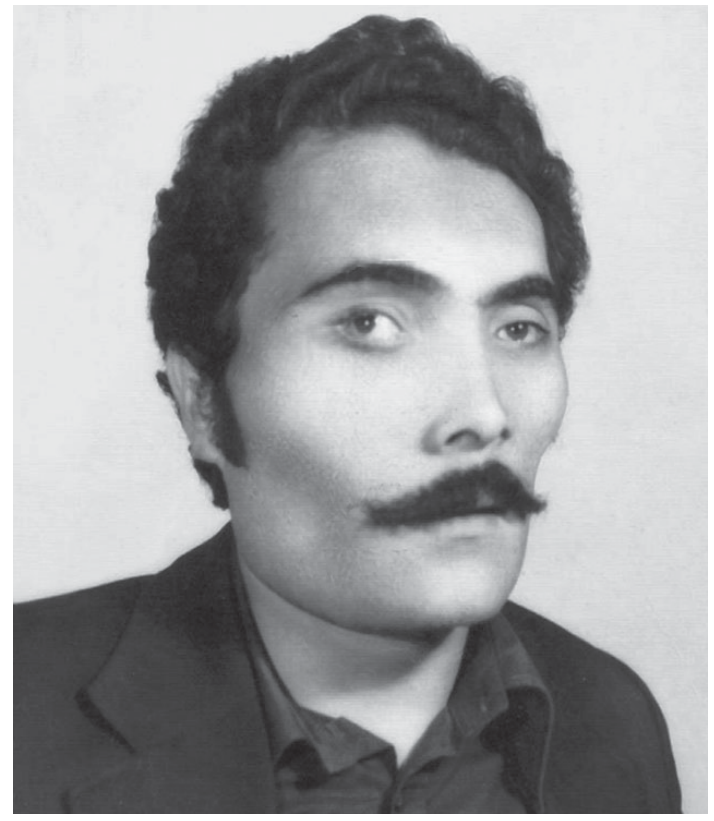

A

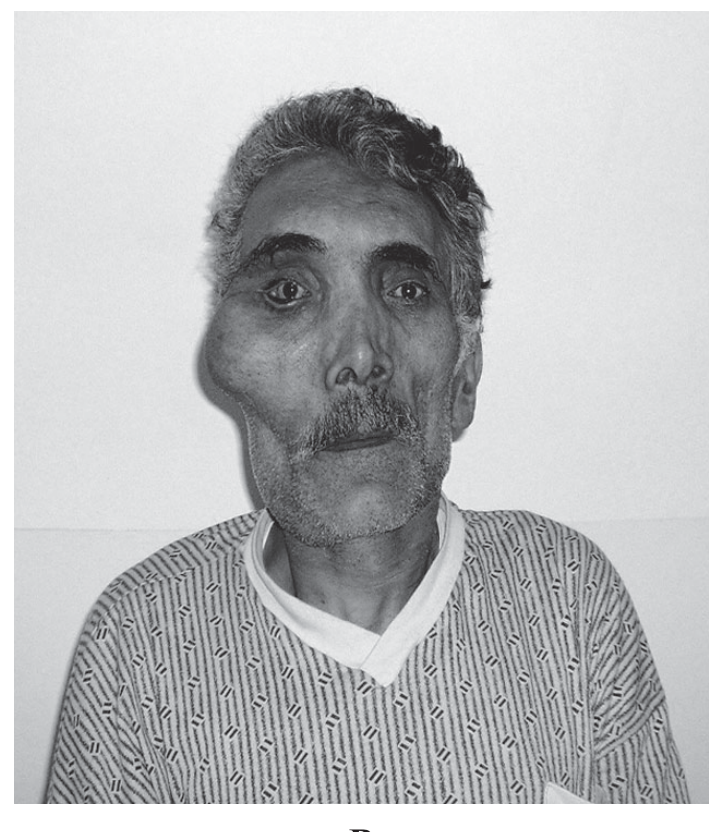

B

Fig. 1. A. 30-year-old man presented with swelling in the right half of the anterior aspect of face and vision loss in the right eye. B. The same man presented with progressive coarsening of the facial features and tumoral lesion involving right maxilla, zygoma, temporal bones protruding to nasal cavity with irregular borders at 52-year-old.

of the distinction between the inner and outer tables. Occipital protuberance was markedly prominent with areas of increased density in the skull bones (Fig. 2B). 
Table 1. Laboratory studies related to endocrine profile of the patient

\begin{tabular}{lcc}
\hline & Values & Reference range \\
\hline Alkaline phosphatase & $1264 \mathrm{U} / \mathrm{L}$ & $0-270$ \\
Ca (serum) & $8.6 \mathrm{mg} / \mathrm{dl}$ & $8.1-10.4$ \\
Phosphorus (serum) & $2.7 \mathrm{mg} / \mathrm{dl}$ & $2.7-4.5$ \\
TSH & $0.09 \mu \mathrm{IU} / \mathrm{Ml}$ & $0.2-4.2$ \\
FT3 & $4.2 \mathrm{pmol} / 1$ & $3.6-6.8$ \\
FT4 & $15.2 \mathrm{pmol} / \mathrm{l}$ & $12-22$ \\
Intact PTH & $126 \mathrm{pg} / \mathrm{ml}$ & $12-65$ \\
Cortisol (serum) & $252 \mathrm{nmol} / \mathrm{L}$ & $171-536$ \\
FSH & $5.60 \mathrm{mIU} / \mathrm{ml}$ & $1.6-11$ \\
LH & $2.52 \mathrm{mIU} / \mathrm{ml}$ & $1.7-8.6$ \\
Total testosterone & $391 \mathrm{ng} / \mathrm{dl}$ & $181-758$ \\
Prolactin & $439.7 \mu \mathrm{IU} / \mathrm{nl}$ & $57-327$ \\
ACTH & $37 \mathrm{pg} / \mathrm{ml}$ & $<120$ \\
25 hydroxyvitamin D3 & $15.8 \mathrm{ng} / \mathrm{ml}$ & $10-40$ \\
Ca (24 hours urinary & $182 \mathrm{mg} / 24 \mathrm{hours}$ & $100-300$ \\
$\quad$ examination) & & \\
Phosphorus (24 hours & $633 \mathrm{mg} / 24 \mathrm{hours}$ & $0-1000$ \\
$\quad$ urinary examination) & & \\
IGF-1 & $890 \mathrm{ng} / \mathrm{ml}$ & $70-97$ \\
\hline
\end{tabular}

Diffuse cortical thickening and sclerosis were seen on the computed tomography of the pelvis and femur. Bone scintigraphy was compatible with the diagnosis of FD (Fig. 3).

The diagnois of acromegaly was established depending on laboratory examination (high IGF-1, glucose suppression test and TRH stimulation test) (Table 2). On cranial magnetic resonance imaging, there were some irregularly thickened areas on all of the cranial bones, especially dominant on the right aspect of the cranium. There was a mass on the left half of the sella, which was $2 \times 1 \mathrm{~cm}$ in diameter. This mass was harbored in the left cavernous sinus (Fig. 4A, 4B).

Because subclinical hyperthyroidism was diagnosed on the laboratory findings, thyroid scintigraphy was planned. On thyroid scan, multinodular goitre with hypoactive and hyperactive areas were detected. On thyroid ultrasound, the right lobe measured $69 \times 21 \times$ $17 \mathrm{~mm}$ with multiple nodules, the largest ones were $14 \mathrm{~mm}$ in the inferior pole and $8 \mathrm{~mm}$ in the central pole of the right lobe. The left lobe measured $61 \times 23 \times$ $29 \mathrm{~mm}$ with multiple nodules, the largest one was $17 \mathrm{~mm}$ in the central part of the left lobe. Fine needle aspiration biopsy was performed to the nodule located in the central part of the left lobe and benign colloidal nodule was diagnosed. The patient was followed up without medication. After 6 weeks free T3, free T4

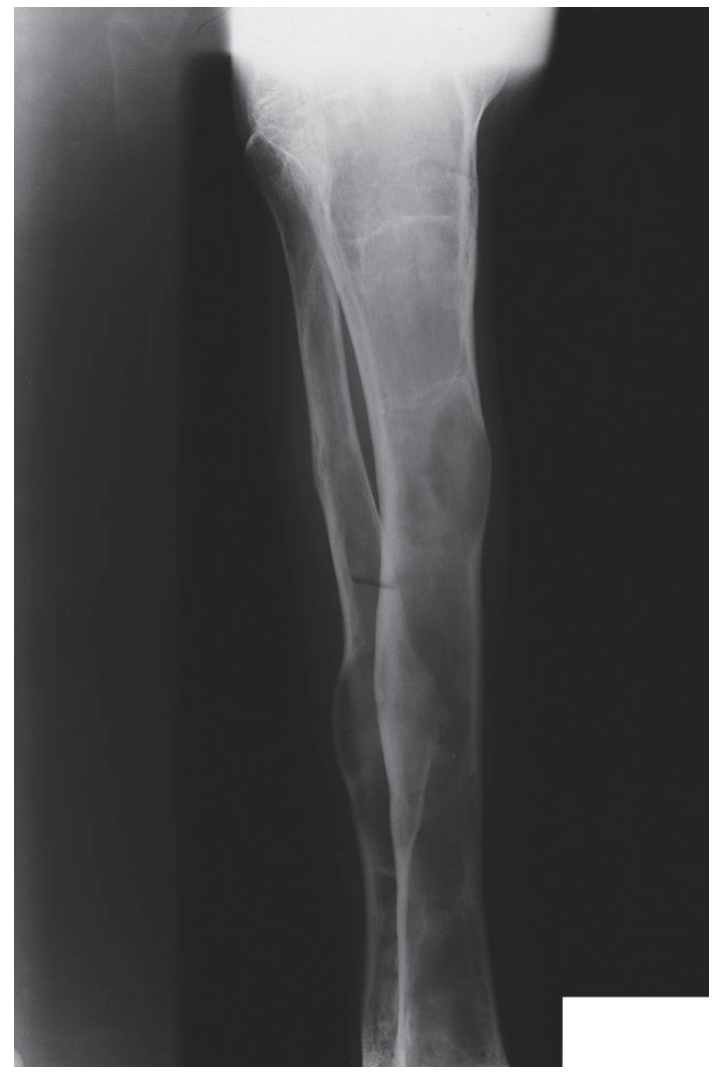

A

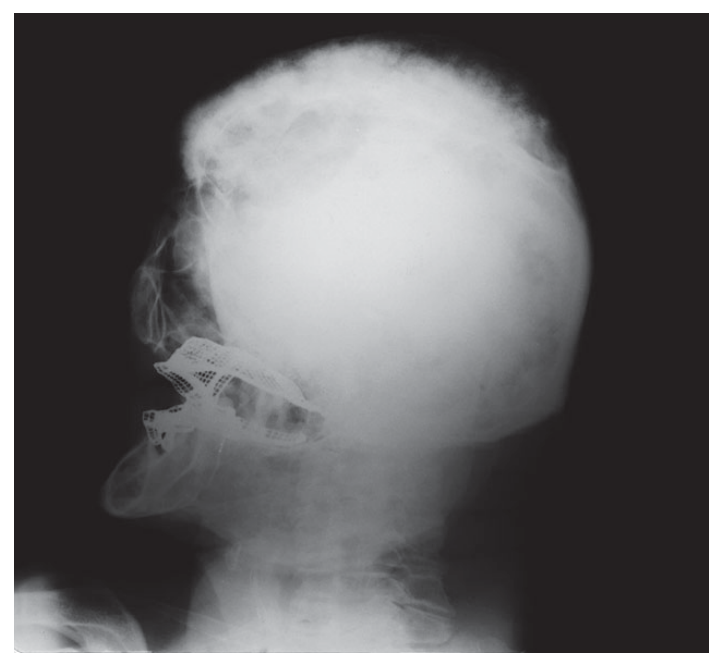

B

Fig. 2. A. Radiographic findings of right lower extremity showing; a ground-glass density with a relative increase in the diameter of medullary space. B. Lateral radiograph of the skull showing; gross enlargement of the skull, facial bones and mandible with irregular thickening of the base and loss of the distinction between the inner and outer tables. There were some increased density areas in the skull bones. 
and TSH were found and were $4.13 \mathrm{pmol} / \mathrm{l}$ (3.6-6.8), $15.3 \mathrm{pmol} / \mathrm{l}(12-22)$ and $0.1 \mu \mathrm{IU} / \mathrm{ml}(0.2-4.2)$, respec-
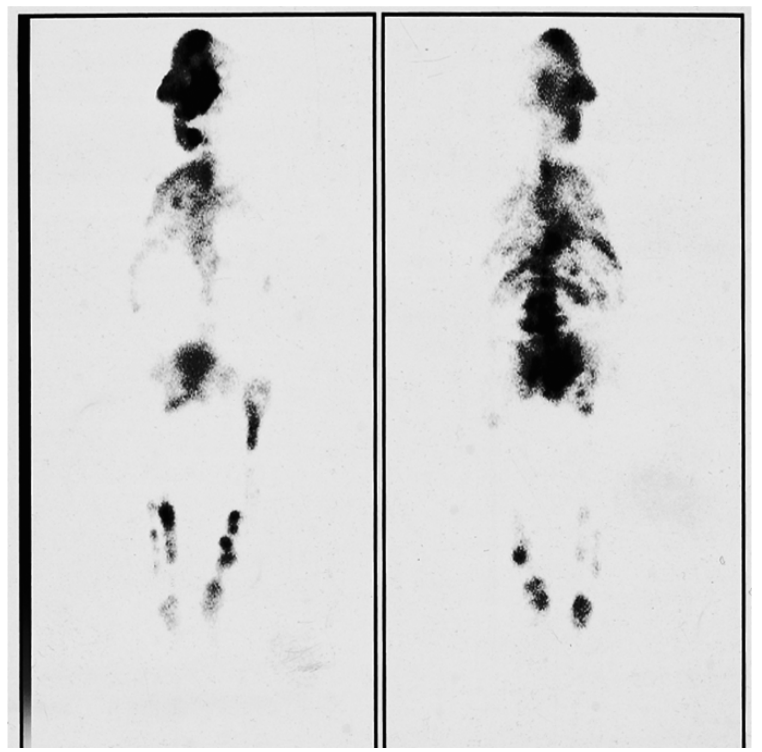

tively. The results of the dynamic tests excluded other kinds of endocrine dysfunction (Table 2).

Calcium (1000 mg/day) and vitamin D3 (800 IU) were given to the patient as an adjuvant therapy combined with oral alendronate to relieve symptoms of the patient and to prevent fractures. Treatment with the

Fig. 3. Whole body bone scintigraphy revealing a nonhomogenous increase in activity in all of the facial bones, especially the maxillozygomatic region and a uniform increase in activity in the frontal and frontoparietal regions in the calvarium. A nonhomogenously increased distribution of activity was found in the vertebral column and all of the ribs. It was also found that the bony structure was expanded in the proximal parts of both of the femurs, distribution of activity in the proximal part of the left femoral diaphysis was increased, and an increased distribution of activity in the right ischium, right fibula and both of the tibia, which was either focal or diffuse, was present.

Table 2. Dynamic tests

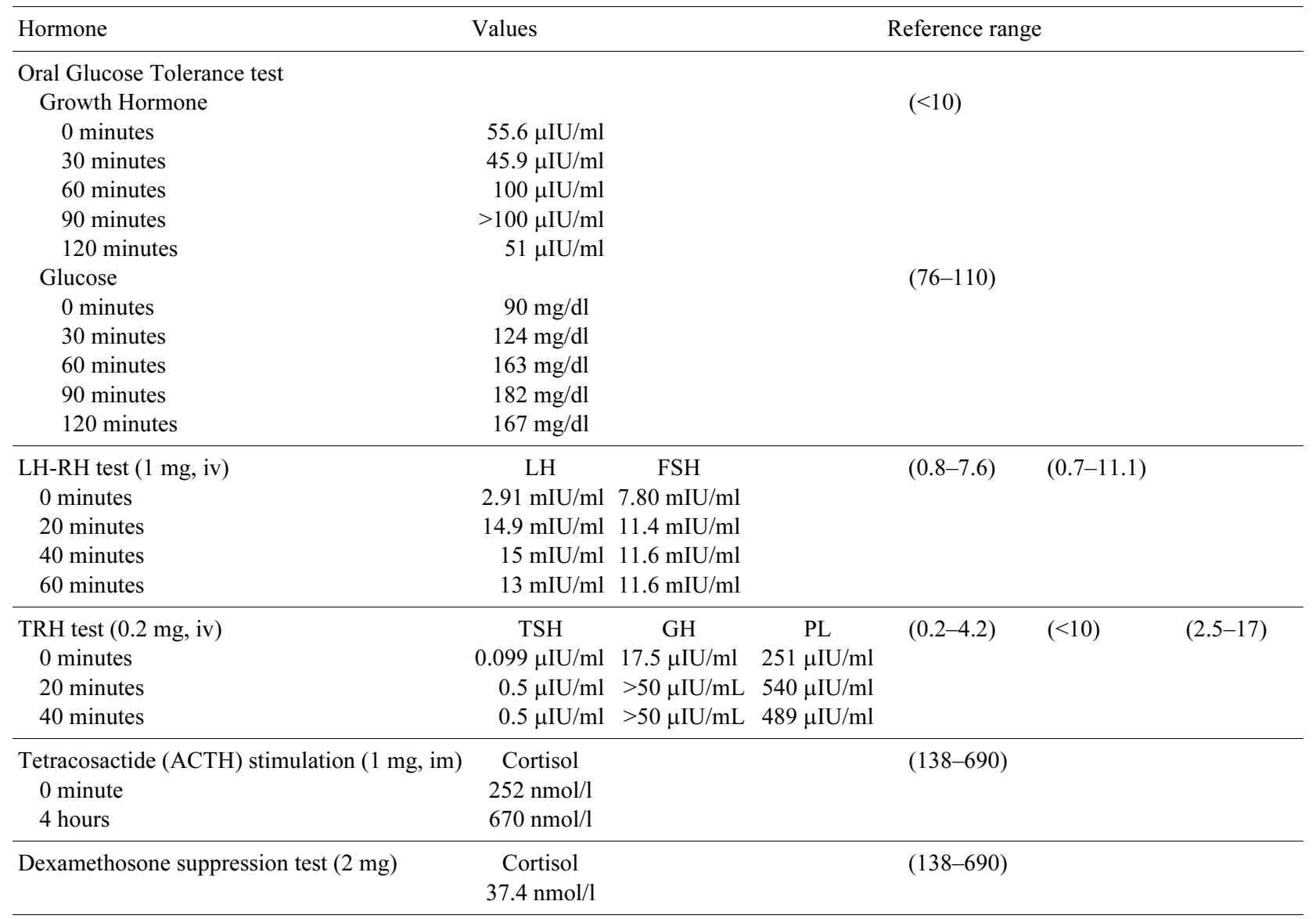


somatostain analogue (octreotide LAR, $20 \mathrm{mg}$ ) was started. The tumoral mass of the FD on the left frontal and temporal bones could only be removed subtotally. The left optic nerve was released. The tumoral mass on

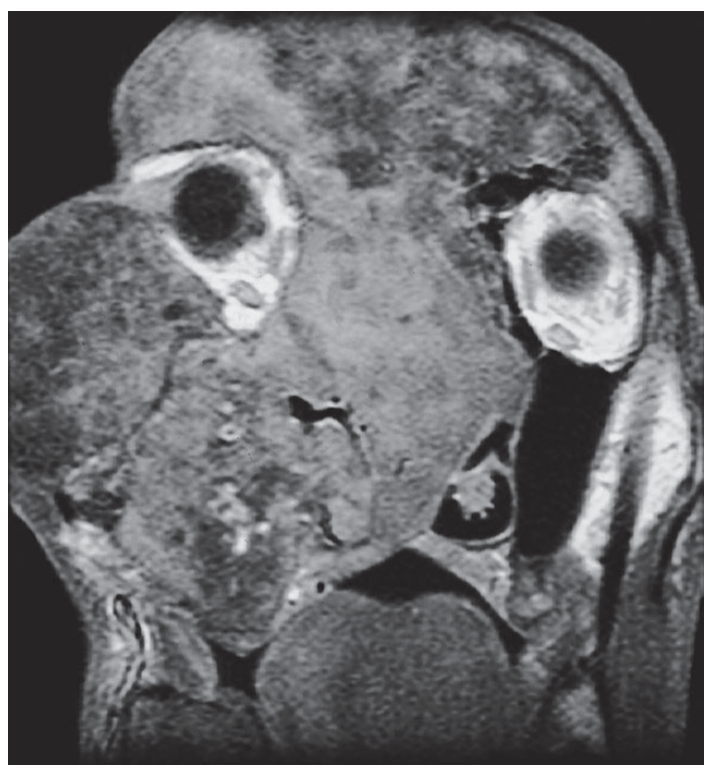

$\mathbf{A}$

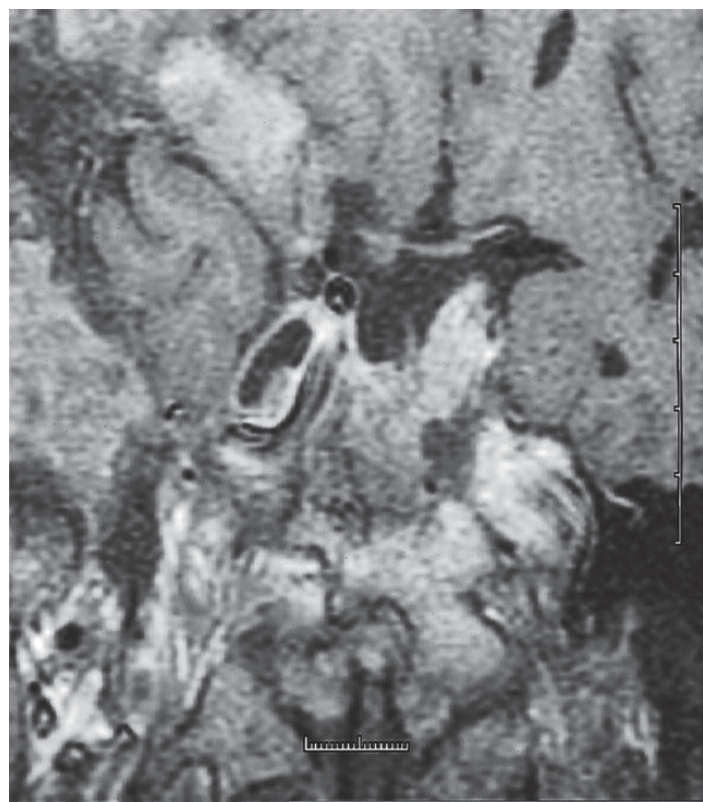

B

Fig. 4. Frontal (A \& B) MRI images demonstrating; a mass on the left half of the sella which was $2 \times 1 \mathrm{~cm}$ in length. In addition, there were some irregular thickening areas on all of the cranial bones, especially dominant on the right aspect of the cranium. the right maxilla and zygomatic process was partially removed. But the pituitary tumor was found inaccessible because of thickness of cranial bones. Histopathology of bone lesion confirmed the diagnosis of FD (Fig. 5). The samples from the craniofacial bones (one from the left frontal bone and the other from the right maxilla) and peripheral blood were taken for the analysis of Gs $\alpha$ mutations. Six months after octreotide treatment, GH level was lowered to $15 \mu \mathrm{IU} / \mathrm{ml}$ and IGF-1 level was lowered to $300 \mathrm{ng} / \mathrm{ml}$.

\section{Methods}

\section{Hormone assay}

Serum $\mathrm{FT}_{4}, \mathrm{FT}_{3}$, were measured by competitive analog immunoassay. TSH, GH, LH and PRL were measured by immunometric assay (DPC, USA). Competitive immunoassay (DPC, USA) was used for measurement of serum cortisol. FSH, total testosterone and intact PTH were measured by two site chemiluminescent immunometric assay, competitive chemiluminescent enzyme assay and chemiluminescence immunoassay, respectively (DPC, USA). ACTH was measured by ELISA (DRG International Inc, USA). IGF-1 and 25-0H Vit D3 were measured by IRMA (CIS Biointernational, France) and RIA (IDS, Bolden, UK), respectively.

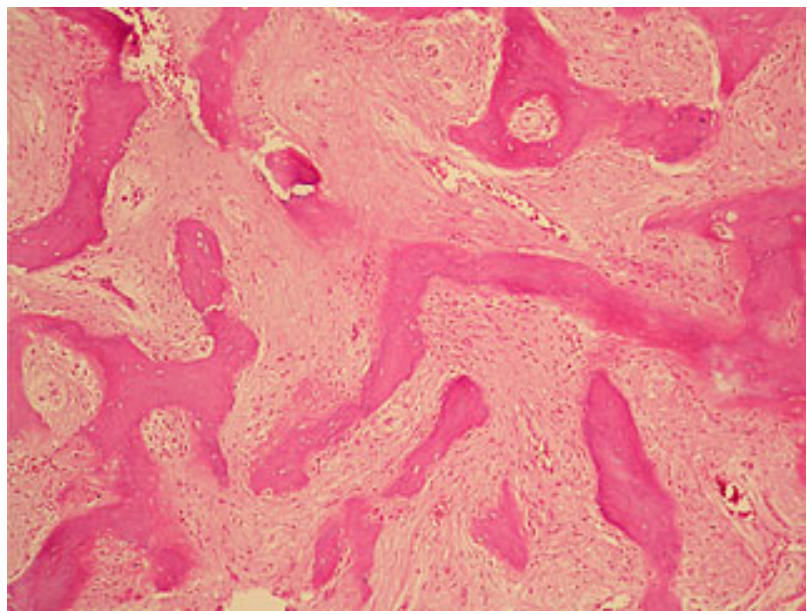

Fig. 5. Hematoxylin- and eosin-stained sections (original magnification, $\times 125$ ) of bone from the maxilla showing irregular bone trabeculae infiltrated with benign spindle cells. 


\section{Direct sequencing}

DNA samples were isolated from the bone tissues and blood by using phenol-chloroform methodology with slight modifications [26, 27]. A DNA fragment including exon 8-9 of Gs $\alpha$ gene was amplified using primers and polymerase chain reaction (PCR) conditions as described by Spambalg et al. [28]. All samples were directly sequenced by using sequenase II and the DYEnamic ET Terminator Cycle Sequencing Kit (Amersham Biosciences, USA) in an ABI Prism 310 automatic sequencer (Applied Biosystems, USA). Protocols were used according to the manufacturer manual.

\section{Result}

Genomic DNAs were isolated from the samples taken from the bone tissues (one from the frontal bone and the other from maxilla) and blood lymphocytes. Exons 8 and 9 of Gs $\alpha$ gene were amplified by PCR. In order to demonstrate the place of mutation, automatic sequencing was done and an Arg $201 \mathrm{Cys}$ (cgt $\rightarrow$ tgt) mutation was found in genomic DNAs which were isolated from the samples taken from the bone tissue, but not in genomic DNA isolated from blood (Fig. 6A, 6B).

\section{Discussion}

Here we report another case of a variant of MAS presented as polyostotic FD, hyperthyroidism and acromegaly. MAS is defined classically by the triad of café-au-lait pigmentation of the skin, precocious puberty, and polyostotic FD. The diagnosis of the MAS requires at least the presence of two components of the triad [29].

Bony lesions may be monostotic or polyostotic. Monostotic is the most common form and the majority of the lesions are located in the craniofacial bones or ribs. Involvement of the facial bones may give a leonine appearance (Leontiasis ossea) to the face. Polyostotic FD is characterized by replacement of multiple bones by fibrous tissue $[30,31]$. In this case, polyostotic FD with involvement of the craniofacial bones, ribs, vertebrae, pelvis, femur, and tibia were noted.

The most common extraskeletal involvement is skin lesions. These lesions consist of isolated dark brown to light brown macules [30]. But typical skin pigmenta-
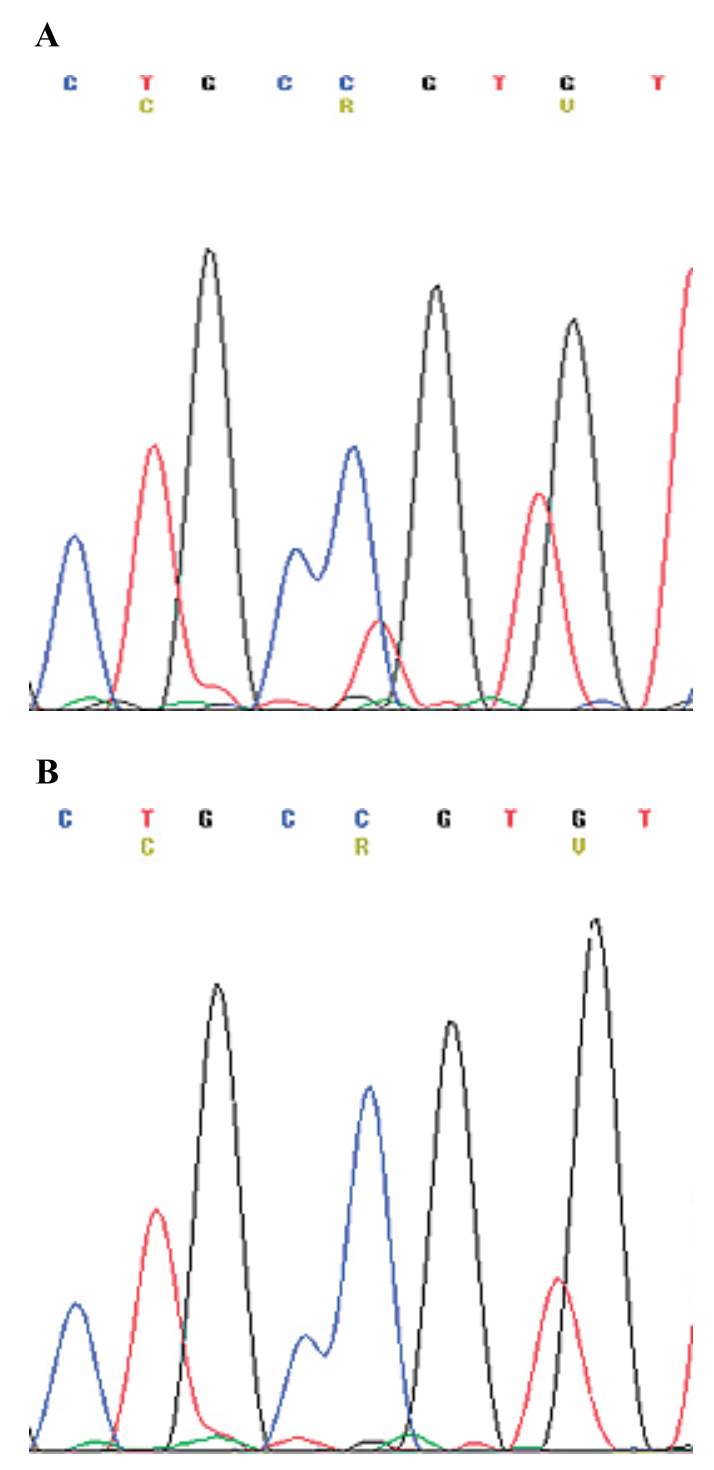

Fig. 6. Automatic sequencing result of samples taken from the bone tissue (A) and blood (B); the mutations associated with substitution of $\mathrm{Arg}^{201}$ by Cys (cgt $\rightarrow$ tgt) demonstrated in the genomic DNA isolated from tissue taken from the frontal bone of the patient (A) but not in the genomic DNA isolated from the blood (B).

tions were lacking in some of their variants, especially in males [2] as in our case.

The sexual precocity is mostly found in females [30]. It has seldomly been observed in males [2]. Sexual precocity was not observed in our case.

Thyroid disorder in MAS is the second most common endocrinopathy [32]. Our case presented with subclinical hyperthyroidism. Review of the literature showed 65 cases with thyroid abnormality $[25,32]$ including nodular or diffuse goiter in $70 \%$. Meanwhile 
$77 \%$ of them are associated with hyperthyroidism, and $28.5 \%$ are associated with subclinical hyperthyroidism [32].

Acromegaly is mentioned in 59 cases to date in MAS $[2,3]$. Less than half the patients with MAS and acromegaly show radiologic evidence of a pituitary tumor $[33,34]$. We presented a case of MAS and acromegaly with pituitary tumor. There are some differences between acromegaly seen with MAS and classical acromegaly. Patients with MAS are generally younger than classical cases of acromegaly [33]. Regarding the patient's history, the complaints of our patient also started after the age of 12 . In classical acromegaly, pituitary adenoma is demonstrated in up to $80-90 \%$ of the patients; on the other hand it is demonstrated in less than half of the patients with the MAS [33, 34]. Hyperprolactinemia is a feature of 30$40 \%$ of patients with classic acromegaly. By comparison in acromegaly with MAS, hyperprolactinemia is demonstrated in $85 \%$ of the patients with MAS [34]. In this case, PRL level was slightly elevated and response of the PRL to TRH was not found as was expected. This might be related to the compression of the pituitary stalk due to the pituitary tumor. GH response to TRH stimulation test is characteristic of acromegaly and is a constant feature for MAS with acromegaly [34]. Increase in serum GH after TRH was also demonstrated in this case.

In addition to precocious puberty, endocrine manifestations related with hyperfunction of somatotroph, thyroid and adrenal cortex may be caused by somatic mutation of Gs $\alpha$. A somatic mutation of Gs $\alpha$ occurring early in embryogenesis (postzygotic mutation) could lead to constitutively increased cAMP to stimulate both proliferation and function of these cell types [6]. It is believed that the somatic mutation in the Gs $\alpha$ gene in osteoblastic cells results in overproduction of a disorganised collagenous matrix. Mutations of the Gs $\alpha$ gene may induce abnormalities in the control of osteoblast growth and differentiation. Gs $\alpha$ mutations may also stimulate osteoblastic cell proliferation by inducing chronic stimulation of early genes like as cfos and c-jun that results in overproduction of fibrotic bone matrix [29]. The mutations in the Gs $\alpha$ gene may be caused by two point mutations, one of them resulting in substitution of $\mathrm{Arg}^{201}$ by His or Cys and the other resulting substitution of the $\operatorname{Gln}^{227}$ amino acid. But there is no documented case of MAS associated with substitution of the Gln ${ }^{227}$ amino acid until now [32]. In very few cases, arginine is replaced by serine, glycine, or leucine $[16,17]$. In another study, a novel, complex heterozygous mutation (one is a combination mutation in the same allele at codons 209 and 210, and the other the missense mutation at codon 235) within Gs $\alpha$ gene in a patient with MAS was demonstrated [23]. To date, Gs $\alpha$ mutations were identified in only very few patients with MAS [3, 7-25]. Gs $\alpha$ mutations were detected in the tissues of ovary $[3,7,14]$, liver $[3,7,18]$, blood $[3,7,8,10]$, thyroid $[3,7,25]$, pituitary adenoma $[7,12,13,15,20]$, adrenals $[3,7,10,22,24]$, testis [3, $7,19]$, thymus [7], lung [7], heart [7], and bone [3, 9, $11,16,23]$ in these studies. The largest study related to this subject was recently published, in which 113 patients with at least one of the signs of MAS were investigated. Overall, the mutation was identified in $43 \%$ of the patients [3].

We also investigated one point mutations of the Gs alpha gene in the bone tissue by direct sequencing. An Arg 201 Cys (cgt $\rightarrow$ tgt) mutation was found in the genomic DNAs isolated from the craniofacial bones (one from frontal bone and the other from maxillar bone), but not in the genomic DNA isolated from the blood. With regard to the blood, the mutation can be detected by employing a more sensitive method than direct sequencing.

In MAS, postzygotic mutation of the Gs $\alpha$ gene leads to a mosaic distribution of mutant cells. Thus, the number of the mutant cells in a given tissue is quite variable and may be very low. The molecular diagnosis of MAS is thus very difficult and is highly dependent on the sensitivity of the detection method [3]. The mutation can be detected by employing a more sensitive method than direct sequencing or other methods. Detection of heterozygous somatic mutations by direct sequencing requires a ratio of mutated to wild type alleles close to 1:1 [35]. The amount of mutated DNA to be detected through direct sequencing was $25-50 \%$ [24]. Therefore, detection of mutant alleles by direct sequencing or another method is less sensitive [12-15, 18-20, 22, 23]. On the other hand, denaturing gradient gel electrophoresis (DGGE) or PCR-based sensitive method may detect mutation even when the ratio of mutant allele is low $[3,7,8,16,17,24,25]$. The minimum amount of mutated DNA required to be detected through DGGE was 3-6\% [24]. Highly sensitive PCRbased technique was first described by Candeliere et al. [17]. This method is based on selective enrichment of mutated DNA [3, 16, 17, 25]. PCR coupled with 
allele-specific oligonucleotide hybridization is another sensitive method which has been used in the detection of the mutated allele [7, 9, 10]. More recently yet another sensitive method has been used to prevent the amplification of the normal allele with the use of protein nucleic acid primer [36]. In spite of using the most sensitive methods, some samples may remain mutation-negative [3]. Functionally normal Gs $\alpha$ protein in patients with MAS has also been reported which suggest a defect beyond the Gs $\alpha$ protein [37].

MAS syndrome is a sporadic disease characterized by the presence of polyostotic FD, café-au-lait pigmentation of the skin, and endocrine dysfunction. Treatment of this disease involves symptomatic relief, and treatment of FD and endocrine dysfunctions. Surgical removal has been the unique treatment of FD. Calcitonin, mithramycin, and etidronate have been tried in a few cases of FD, but they had poor results [38]. Use of antiresorptive drugs has been proposed because of the evidence for increased osteoclastic bone resorption, mediated by the presence of numerous and large osteoclasts at the interface between marrow fibrous areas and bone surfaces. Intravenous pamidronate appears to have potential as a nonsurgical treatment of FD. Vitamin D and calcium must be given as adjuvant therapy with bisphosphonates to prevent possible vitamin deficiency or secondary hyperparathyroidism [39]. Recently, oral bisphosphanates have shown promise in the treatment of FD [40, 41]. The treatment of acromegaly associated with MAS is difficult. Neurosurgery is the treatment of choice. But it is a dangerous procedure due to high vascularity of fibrous bone tissue. Radiotherapy should also be avoided because of the possibility of sarcomatous degeneration. Bromocriptine has limited action. But therapeutic action of octreotide is more promising. It causes not only a decrease in $\mathrm{GH}$, but also a shrinkage of adenomatous tissue [29].

In conclusion, we described a case of MAS associated with Gs $\alpha$ mutations in the bone tissue, presenting with polyostotic FD, subclinical hyperthyroidism and acromegaly. Facial features seen in MAS resemble the ones in acromegaly. So these features have usually been ascribed to FD and acromegaly might have been overlooked. Therefore, all patients with MAS should have careful evaluation for the diagnosis of acromegaly [42].

\section{References}

1. Shires R, White MP, Avioli LV (1979) Idiopathic hypothalamic hypogonadotropic hypogonadism with polyostotic fibrous dysplasia. Arch Intern Med 139: 1187-1189.

2. Bhansalı A, Sharma BS, Sreenivasulu P, Singh P, Vashisth RK, Dash RJ (2003) Acromegaly with fibrous dysplasia: McCune-Albright syndrome. Endocr $J$ 50: 793-799.

3. Lumbroso S, Paris F, Sultan C (2004) Activating Gs $\alpha$ mutations: Analysis of 113 patients with signs of McCune-Albright syndrome - A European collaborative study. J Clin Endocrinol Metab 89: 2107-2113.

4. McCune DJ (1936) Osteitis fibrosa cystica: the case of nine-year-old girl who also exhibits precocious puberty, multiple pigmentation of the skin and hyperthyroidism. Am J Dis Child 52: 743-747.

5. Albright F, Butler AM, Hampton AO, Smith P (1937) Syndrome characterised by osteitis fibrosa disseminata, areas of pigmentation and endocrine dysfunction, with precocious pubety in females: report of five cases. $N$ Engl J Med 216: 727-746.

6. Spiegel AM (1997) The molecular basis of disorders caused by defects in G proteins. Horm Res 47: 89-96.

7. Weinstein LS, Shenker A, Gejman PV, Merino MJ, Friedman E, Spiegel AM (1991) Activating mutations of the stimulatory G protein in the McCune-Albright syndrome. N Engl J Med 325: 1688-1695.

8. Schwindinger WF, Francomano CA, Levine MA (1992) Identification of a mutatin in the gene encoding the alpha subunit of the stimulatory $\mathrm{G}$ protein of adenyl cyclase in McCune-Albright syndrome Proc Natl Acad Sci USA 89: 5152-5156.

9. Shenker A, Weinstein LS, Sweet D, Spiegel AM (1994) An activating Gs alpha mutation is present in fibrous dysplasia of bone in the McCune-Albright syndrome. J Clin Endocrinol Metab 79: 750-755.

10. Boston BA, Mandel S, LaFranchi S, Bliziotes M (1994) Activating mutation in the stimulatory guanine nucleotide-binding protein in an infant with Cushing's syndrome and nodular adrenal hyperplasia. J Clin Endocrinol Metab 79: 890-893.

11. Malchoff CD, Reardon G, MacGillivray DC, Yamase H, Rogol AD, Malcoff DM (1994) An unusual presentation McCune-Albright syndrome confirmed by an activating mutation of the Gs alpha subunit from a bone lesion J Clin Endocrinol Metab 73: 803-806.

12. Dotsch J, Kiess W, Hanze J, Repp R, Ludecke D, Blum WF, Rascher W (1996) Gs alpha mutation at codon 201 in pituitary adenoma causing gigantism in a 6-year-old boy with McCune-Albright syndrome. J Clin Endo- 
crinol Metab 81:3839-3842.

13. Ihara C, Shimatsu A, Murabe H, Kataoka K, Kondo C, Nakao K (1996) Growth hormone-secreting pituitary adenoma associated with multiple bone cysts, skin pigmentation and aortitis syndrome. $J$ Endocrinol Invest 19: 753-757.

14. Pienkowski C, Lumbroso S, Bieth E, Sultan C, Rochiccioli P, Tauber M (1997) Recurrent ovarian cyst and mutation of the Gs alpha gene in ovarian cyst fluid cells: what is the link with McCune-Albright syndrome? Acta Paediatr 86:1019-1021.

15. Tinschert S, Gerl H, Gewies A, Jung HP, Nurnberg $P$ (1999) McCune-Albright syndrome: clinical and molecular evidence of mosaicism in an unusual giant patient. Am J Med Genet 83: 100-108.

16. Rimunicchi M, Fisher LW, Majolagbe A, Corsi A, Lala R, De Santis C, Robey PG, Bianco P (1999) A novel GNAS1 mutation, R201G, in McCune-Albright syndrome. J Bone Miner Res 14: 1987-1989.

17. Candeliere GA, Roughley PJ, Glouriex FH (1997) Polymerase chain reaction based technique for the selective enrichment and analysis of mosaic arg 201 mutations in $\mathrm{G}$ alpha $\mathrm{s}$ from patients of bone with fibrous dysplasia of bone. Bone 21: 201-206.

18. Silva ES, Lumbroso S, Medina M, Gillerot Y, Sultan C, Sokal EM (2000) Demonstration of McCuneAlbright mutations in the liver of children with high $\gamma$ GT progressive cholestasis. J Hepatol 32: 154-158.

19. Coutant R, Lumbroso S, Rey R, Lahlou N, Venara M, Rouleau S, Sultan C, Limal JM (2001) Macroorchidism due to autonomous hyperfunction of Sertoli cells and Gs $\alpha$ gene mutation: an unusual expression of McCune-Albright syndrome in a prepubertal boy. $J$ Clin Endocrinol Metab 86: 1778-1781.

20. Riminucci M, Collins MT, Lala R, Corsi A, Matarazzo P, Gehron Robey P, Bianco P (2002) An R201H activating mutation of the GNAS1 (Gs $\alpha)$ gene in a corticotroph pituitary adenoma. Mol Pathol 55: 58-60.

21. de Sanctis L, Romagnolo D, Greggio N, Genitori L, Lala R, de Sanctis C (2002) Searching for Arg201 mutations in the GNAS1 gene in Italian patients with McCune-Albright syndrome. $J$ Pediatr Endocrinol Metab 15 (Suppl 3): 883-889.

22. Paris F, Lumbroso S, Reingard I, Attal G, Echenne B, Dumas R, Sultan C (1999) An unusual presentation of McCune-Albright syndrome in a newborn confirmed by identification of Gs alpha mutation in blood and adrenal gland. 38th Annual meeting of the ESPE. Horm Res 51 (Suppl 2): 65 (Abstract).

23. Song HD, Chen FL, Shi WJ, Wang S, Zhang Q, Hu RM, Chen JL (2002) A novel, complex heterozygous mutation within Gs $\alpha$ gene in patient with McCuneAlbright syndrome. Endocrine 18: 121-128.

24. Fragoso MC, Domenice S, Latronico AC, Martin RM, Pereira MA, Zerbini MC, Lucon AM, Mendonca BB
(2003) Cushing's syndrome secondary to adrenocorticotropin-independent macronodular adrenocortical hyperplasia due to activating mutations of GNAS1 gene. J Clin Endocrinol Metab 88: 2147-2151.

25. Collins MT, Sarlis NJ, Merino MJ, Monroe J, Crawford SE, Krakoff JA, Guthrie LC, Bonat S, Robey PG, Shenker A (2003) Thyroid carcinoma in the McCune-Albright syndrome: contributory role of activating Gs $\alpha$ mutations. J Clin Endocrinol Metab 88: 4413-4417.

26. Gross-Bellard M, Oudet P, Chambon P (1973) Isolation of high-molecular weight DNA from mammalian cells. Eur J Biochem 36: 32-38.

27. John SW, Weitzner G, Rozen R, Scriver CR (1991) A rapid procedure for extracting genomic DNA from leukocytes. Nucleic Acids Res 19: 408.

28. Spambalg D, Sharifi N, Elisei R, Gross JL, MedeirosNeto G, Fagin JA (1996) Structural studies of the thyrotropin receptor and Gs alpha in human thyroid cancers: low prevalence of mutations predicts infrequent involvement in malignant transformation. J Clin Endocrinol Metab 81: 3898-3901.

29. Yavuzer R, Khilnani R, Jackson IT, Audet B (1999) A case of atypical McCune-Albright syndrome requiring optic nerve decompression. Ann Plast Surg 43: 430435.

30. Kumawat DC, Bomb BS, Agarwal HK, Bhatnagar HNS (1987) The Albright syndrome associated with acromegaly and hyperthyroidism. J Postgrad Med 33: 155-157.

31. Kupcha PC, Guille JT, Tassanawipas A, Bowen R (1991) Polyostotic fibrous dysplasia and acromegaly. J Pediatr Orthoped 11: 95-99.

32. Mastorakos G, Mitsiades NS, Doufas AG, Koutras AD (1997) Hyperthyroidism in McCune-Albright syndrome with a review of thyroid abnormalities sixty years after the first report. Thyroid 7: 433-439.

33. Chanson P, Dib A, Visot A, Derome PJ (1994) McCune-Albright syndrome and acromegaly. Clinical studies and response to treatmant in five cases. Eur $J$ Endocrinol 131: 229-234.

34. Premawardhana LDKE, Vora JP, Mills R, Scanlon MF (1992) Acromegaly and its treatment in the McCuneAlbright syndrome. Clin Endocrinol 36: 605-608.

35. Trulzsch B, Krohn K, Wonerow P, Paschke R (1999) DGGE is more sensitive for the detection of somatic point mutations than direct sequencing. Biotechniques 27: 266-268.

36. Bianco P, Rimunicchi M, Majologbe A, Kuznetsov SA, Collind MT, Mankani MH, Corsi A, Bone HG, Wientroub S, Spiegel AM, Fisher LW, Robey PG (2000) Mutations of the GNAS1 gene, stromal cell dysfunction and osteomalacic changes in non-McCuneAlbright fibrous dysplasia of bone. J Bone Miner Res 15: $120-128$. 
37. Gessl A, Freissmuth M, Czech T, Matula C, Hainfellner JA, Buchfelder M, Vierhapper H (1994) Growth hormone-prolactin-thyrotropin secreting pituitary adenoma in atypical McCune-Albright syndrome with functionally normal Gs $\alpha$ protein. J Clin Endocrinol Metab 79: 1128-1134.

38. Long A, Loughlin T, Towers RP, McKenna TJ (1988) Polyostotic fibrous dysplasia with contrasting responses to calcitonin and mithramycin; aetiological and therapeutic implications. Int J Med Sci 157: 229-234.

39. Chapurlat RD, Delmas PD, Liens D, Meunier PJ (1997) Long-term effects of intravenous pamidronate in fibrous dysplasia of bone. J Bone Miner Res 12:
1746-1752.

40. Khadilkar VV, Khadilkar AV, Maskati GB (2003) Oral bisphosphonates in polyostotic fibrous dysplasia. Indian Pediatr 40: 894-896.

41. Lane JM, Khan SN, O'Connor WJ, Nydick M, Hommen JP, Schneider R, Tomin E, Brand J, Curtin J (2001) Bisphosphonate therapy in fibrous dysplasia. Clin Orthop Relat Res 382: 6-12.

42. Cuttler L, Jackson JA, Saeed Uz-Zafar M, Levitsky LL, Mellinger RC, Frohman LA (1989) Hypersecretion of growth hormone and prolactin in McCune-Albright syndrome. J Clin Endrinol Metab 68: 1148-1154. 